\title{
JACOBS AND JACOBITES: THE SYRIAN ORIGINS OF THE NAME AND ITS EGYPTIAN ARABIC INTERPRETATIONS
}

By the time of the Muslim conquests of the Middle East, Eastern Christianity had experienced numerous divisions caused by ideological and political confrontations. Controversies over the union of the divinity and the humanity of Christ, perceived as an essential point of Christian doctrine, as well as the Byzantine imperial policy, aiming at strengthening Byzantium's influence in Syria, Arabia, the Caucasus, and Egypt, had resulted in the separation of the ethno-religious communities of these provinces from Byzantium. The controversies remained unsettled, and the divisions, created by them, continued. To a Muslim observer, Eastern Christianity looked like a hodgepodge of various denominations among which the following three were the most influential: the Syro-Persian Christianity, the Graeco-Roman Orthodoxy, and the anti-Chalcedonian faction, insisting on "one nature" of Christ. The Muslim jurist and doxographer Muḥammad ašŠahrastānī (1076-1153) summarized this as follows in his celebrated Book of Religions and Sects (Kitäb al-milal wa-n-nihal): "Then Christians split up into seventy two sects, ${ }^{1}$ the three big divisions among them being: the Melkites, the Nestorians, and the Jacobites." ${ }^{2}$ A similar view of the Christian divisions, differentiating between three main communities, is also found in the Christian author 'Alī ibn Dāwūd al-Arfādī's The Book of the Concordance of Faith (Kitāb iğtimā' al-amāna), influenced by the Islamic doxographical tradition: "[Christians] are reducible to three divisions (firaq), for they ascend to three denominations (mad̄āhib)

(1) The notion that the Christians were divided into seventy-two groups was probably influenced by Muslim Hadits: see G. H. A. JuYNBOLL, Encyclopedia of Canonical Hadith, Leiden, Boston, 2007, pp. 437, 458.

(2) W. Cureton, Muhammad al-Shahrastáni, Kitāb al-milal wa-n-nihal. Book of Religious and Philosophical Sects, London, 1842, pt. 1, p. 173. 
as their roots, namely the division of the Nestorians, the division of the Melkites, and the division of the Jacobites; everything that exists apart from these three communities (al-milal) are [in fact] divisions which originate from them and are reducible to them." 3

It is a conventional view that the denomination of Jacobites owes its name to Jacob Baradaeus (West-Syriac: Burd 'on $\overline{\text { ) }}$, the sixth-century Syrian bishop ${ }^{4}$ who was instrumental in establishing a church hierarchy separate from and standing in opposition to the Chalcedonian one, recognized by the Byzantine authorities. ${ }^{5}$ This notion of the origins of the term "Jacobites" is based on both Syriac and Greek sources. Thus, Michael the Great, the famous West-Syrian chronicler, wrote about it as follows: "Jacob of [the monastery of] Psilta, who was ordained [bishop] for Edessa, went about the countries of the East and bestowed ordination upon the Orthodox [i.e. the anti-Chalcedonians]. He put the appearance of a vagabond, especially while en route, for fear of persecutions." 6 Another famous West-Syrian author, Gregorius

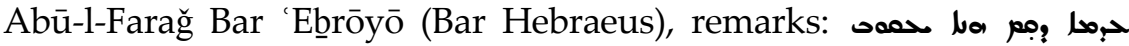
(10....until this Jacob appeared, and then they increased in number. And because of this they were called Jacobites after him." ${ }^{\prime 7}$

(3) Н. Н. СЕАЕЗНЕВ, “Западносирийский книжник из Арфа̄да и иерусалимский митрополит Церкви Востока. «Книга общности веры» и ее рукописная редакция на каршуни" [A West-Syrian bookman from Arfād and the East-Syriac Metropolitan of Jerusalem. "The Book of the Concordance of Faith" and Its Manuscript Recension in Garshūnī], Символ 58: Syriaca \& Arabica (2010), c. 47 (text in Garshūnī), p. 74 (Russian translation); G. TROUPEAU, "Le livre de l'unanimité de la foi de 'Alī ibn Dāwud al-Arfādī," Melto, 5:2 (1969), pp. 201, 203 (Arabic text); pp. 200, 202 (French translation); repr. in G. TROUPEAU, Études sur le christianisme arabe au Moyen Âge (Variorum Collected Studies Series, CS515), Aldershot, Brookfield, 1995, no. XIII.

(4) For a survey of sources concerning Jacob Baradaeus, including his biographical data, see D. D. BUNDY, "Jacob Baradaeus. The State of Research, A Review of Sources and a New Approach," Mus, 91 (1978), pp. 45-86.

(5) J.-M. FIEY, Saints syriaques (Studies in Late Antiquity and Early Islam, 6), Princeton, NJ, 2004, pp. 106-107, 110-111.

(6) J.-B. Снавот, Michel le Syrien, Chronique, t. I-IV, Paris, 18991910, t. IV, p. 310, col. 1 (text); t. II, pp. 245-246 (French translation).

(7) J.-B. AbBELOOS, Th. J. LAMY, Gregorius Barhebraeus, Chronicon Ecclesiasticum, t. I-III, Lovanii, Parisiis, 1872-1877, t. I, p. 217 (text), p. 218 (Latin translation). 
It is worth mentioning, however, that the adjective "Jacobite" (حمدحم) was associated, in its use by the Syrians, not only with the name of Jacob Baradaeus, but also with the famous Syriac poet Jacob of Sarug, bishop of Baṭān (fifth-sixth century). The twelve-syllable metre typical of Jacob of Sarug's hymns was called "Jacobite" after him. ${ }^{8}$

As one of the earliest Greek witnesses to the origins of the name "Jacobites," one should point out the treatise On Heresies by John of Damascus:

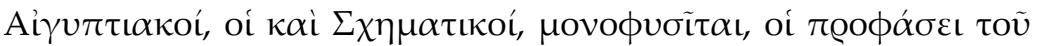

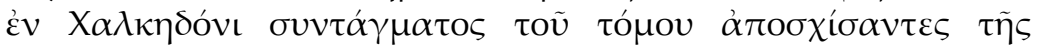

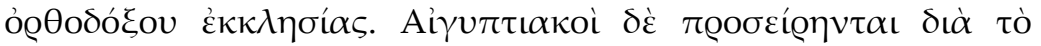

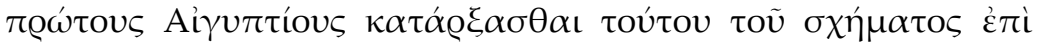

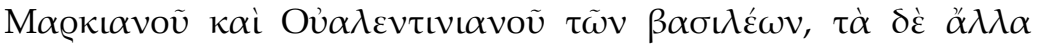

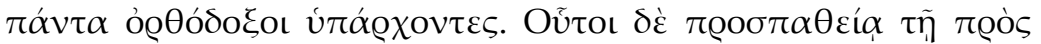

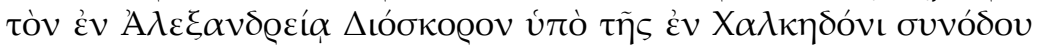

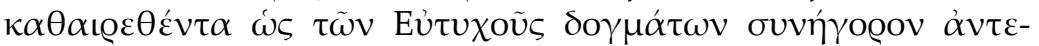

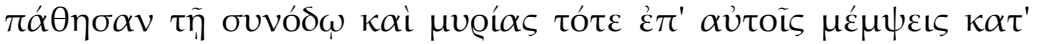

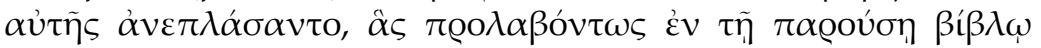

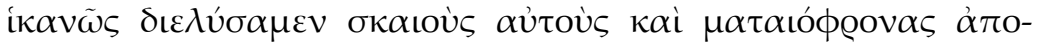

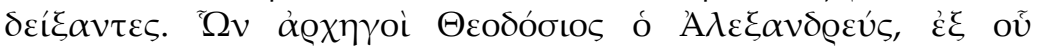

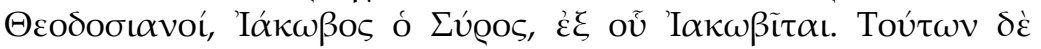

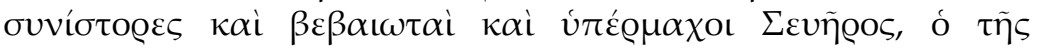

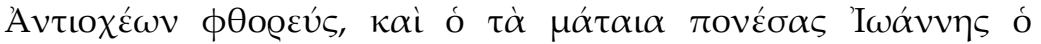

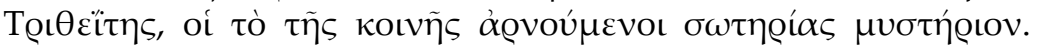

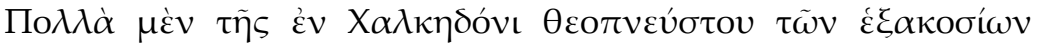

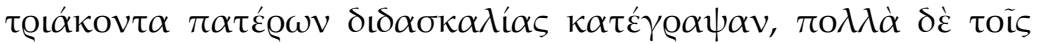

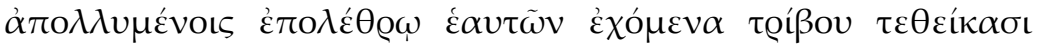

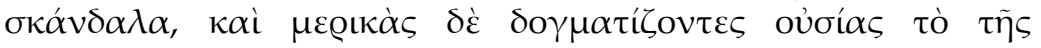

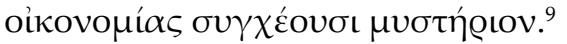

The Egyptians, who are also called Schematics/Schismatics ${ }^{10}$ and Monophysites, separated from the orthodox Church on the pretext of that document <approved > at Chalcedon [and known as] the Tome. They have been called Egyptians because of the fact that during the reign of Emperors Marcian and Valentian the

(8) R. PAyne SMith [et al.], Thesaurus syriacus, t. I-II, Oxonii, 18791901, t. I, p. 1614.

(9) S. Joannis Damasceni, De hæresibus compendium, 83:11, PG 94, 741744.

(10) See footnote 60 in: S. Joannis Damasceni, De hæresibus compendium, PG 94, 741. 
Egyptians were the first authors of this particular kind of heresy, being orthodox in what concerns the rest. Because of their strong attachment to Dioscorus of Alexandria, who was deposed by the Council of Chalcedon for defending the teachings of Eutyches, they opposed this council and to the limit of their ability fabricated innumerable charges against it, which charges we have already taken up in this book and sufficiently refuted by showing them to be clumsy and stupid. Their leaders were Theodosius of Alexandria, from whom come the Theodosians, and Jacob the Syrian, from whom come the Jacobites. ${ }^{11}$ Privy to these as champions and strong defenders were Severus, the seducer from Antioch, and John the Tritheite <i.e. John Philoponus>, who expended his efforts on vain things. Both of these last denied the mystery of the common salvation. They wrote many things against the inspired council of the 630 Fathers of Chalcedon, and they set many snares, so to speak, and laid stumbling blocks by the wayside for those who are lost in their pernicious heresy. Also by holding the doctrine of individual substances, they destroy the mystery of the Incarnation. ${ }^{12}$

"Jacob the Syrian, from whom come the Jacobites": this seems to be a definite identification of the origin of this denomination's name. It is, however, worth calling attention to the fact that the evidence from other Greek sources is not so definite. If one explores the relevant passage in the Narratio de Rebus Armeniae, for instance - a Greek document of the same period, written from the Chalcedonian point of view - one will find that the origin of the name "Jacobites" is associated there with the aforementioned Jacob of Sarug (or of Bațnān), and not with Jacob Baradaeus:

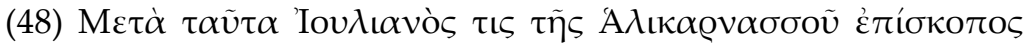

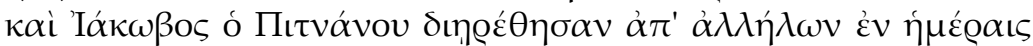

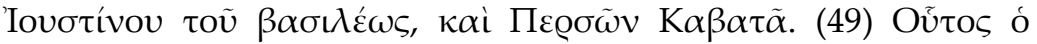

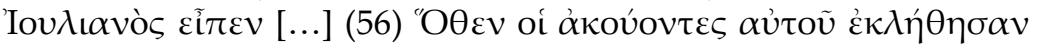

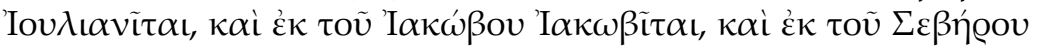
$\sum \varepsilon \beta \eta$ † $\alpha$ voí.

(11) Cf.: Qawl radd 'alā at-tāwudūsiyya ay al-ya 'āqiba fì-t-țabì' a al-wāhida, in J. C. LAmoreaux, "An Arabic Version of Leontius of Byzantium's Thirty Chapters," Mus, 108 (1995), pp. 343-365 (esp. p. 348).

(12) On Heresies, 83. I reproduce, with a few modifications, the English translation of Fr. H. CHASE, Saint John of Damascus, Writings (The Fathers of the Church, A New Translation, 37), New York, 1958, pp. 138-139. 
(48) After this, Julian, bishop of Halicarnassus, and Jacob of Batnan separated from each other in the days of the emperor Justin and of the king of Persians Kabad. (49) This Julian said <...> (56) Consequently, his followers were called Julianists, and those of Jacob - Jacobites, and those of Severus - Severians. ${ }^{13}$

Considering that the origin of the name "Jacobites" was associated with Jacob of Sarug in such a relatively early source as the Narratio de Rebus Armeniae, it is not surprising to find a similar association in the treatise of a much later Arabic-speaking Coptic author al-Mu'taman ibn al-'Assāl (the thirteenth century), The Summa of the Foundations of Religion and the Traditions (lit. What was Heard) of Reliable Knowledge (Mağmū' ușūl ad-dīn wa-masmū 'mahșūl al-yaqīn). In the eighth chapter of this work, al-Mu'taman ibn al- 'Assāl retells, among other subjects, the treatise of the Arabic-speaking author of the East-Syriac ("Nestorian") Christian tradition Abū-l-Farağ 'Abd Allāh ibn aṭ-Ṭyyib al'Irāqī (-1043), ${ }^{14}$ where he says the following:

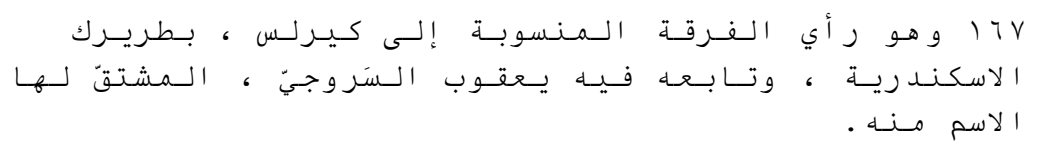

167. This is the opinion of the division <of Christians>, related to Cyril, patriarch of Alexandria, in which he was followed by Jacob of Sarug, from whom they got their name <Jacobites $>.{ }^{15}$

(13) G. GARITTE, La Narratio de Rebus Armeniae (CSCO, 132, Subs. 4), Louvain, 1952, p. 34; В. А. АРУТЮНОВА-ФИДАНЯН, «Повествование о делах армянских» (VII в.). Источник и время [Narratio de Rebus Armeniae (7th century). The source and its time], Москва, 2004, с. 164-167. Both Garitte and Arutyunova-Fidanyan "correct" the author of the treatise by supplying the passage with their commentaries about Jacob Baradaeus as if the latter is explicitly mentioned in the original text (GARITTE, La Narratio de Rebus Armeniae, рр. 125-126; АРутюНОВА-ФИДАНЯН, «Повествование о делах армянских», c. 232 , сн. 95$)$.

(14) Н. Н. СЕЛЕЗНЕВ, “Несторианский философ в коптской книжности: Ибн ат-Таййиб в пересказе Ибн ал-Ассаля" [A Nestorian Philosopher in the Arabic Literature of the Copts: Ibn at-Tayyib as Retold by Ibn al'Assāl], История философии, 16 (2011), с. 265-280. The publication includes a Russian translation of the treatise by Ibn aț-Ṭayyib as retold by Ibn al- 'Assāl (c. 270-276).

(15) A. Wadi [=W. AbULLIF], PIRONE B., al-Mu'taman Abū Isḥāq Ibrāhīm Ibn al-'Assāl, Mağmū' ușūl ad-dīn wa-masmū' mahșūl al-yaqīn. Summa dei principi della Religione (SOC, Monographiae, 6a-9), Cairo, Jerusalem, 1998, vol. 1 (SOC, 6a), p. 199. In the second part of the Chronicle of Se'ert (ch. 21) Jacob 
Let us now focus on traditions concerning Jacob Baradaeus. In the Arabic Christian literature of Egypt, they were gathered together and connected to the name "Jacobites" by the Melkite patriarch Eutychius also known as Sa 'ìd ibn al-Bitrīq (or al-Bațīq, if his name is transcribed in accordance with its colloquial pronunciation;"16 876/7-940; patr. 933-940). In his History, Compiled with Verification and Confirmation (at-Ta'rīh al-mağmū' 'alā-t-tahqīq wa-t-tașdìq; § 249) he wrote:

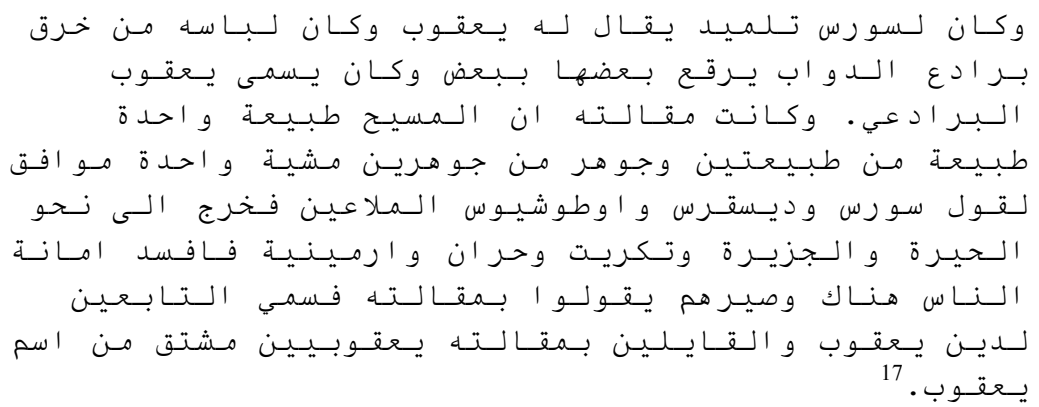

Severus had a disciple named Jacob whose clothes were made of shreds of saddle-cloths (barädi ) of pack animals bound together. $<$ For this reason $>$ he was called Jacob Baradaeus (al-Barādi $\bar{\imath}-$ "Saddler"). His teaching was that Christ is one nature, nature from two natures, and essence from two essences, one will, which was in accordance with the sayings of the accursed Severus, Dioscorus, and Eutychius. He went about the countries of al-Hīra, alĞazīra, Tikrit, Harrān, and Armenia, and corrupted the faith of the people there. He made so that they accepted his teaching. The followers of the religion of Jacob and those who spoke according to his teaching were called "Jacobites," <a term> that comes from the name "Jacob."

The interesting detail provided by Sa 'id ibn al-Bițrīq's account that Jacob was a disciple of the anti-Chalcedonian patriarch of Antioch Severus (456-538; patr. 512-518) - is confirmed by the History of

Baradaeus is also introduced into the narrative as a follower and propagator of the doctrine of Jacob of Sarug. A. SCHER, Histoire nestorienne (Chronique de Séert). Seconde partie (I) (PO, 7:2), Paris, 1909, repr. 1950, p. 140/[48].

(16) The name etymologically comes from the Latin patricius via the Greek татеíkıьs.

(17) M. BREYDY, Das Annalenwerk des Eutychios von Alexandrien. Ausgewählte Geschichten und Legenden kompiliert von Sa id ibn Batrīq um 935 A.D. (CSCO, 471-472; Scr. Ar. 44-45), Lovanii, 1985, t. 471, Scr. Ar. 44, p. 102 (text), t. 472, Scr. Ar. 45, p. 85 (German translation). 
another Arabic-speaking Coptic author Buțus ibn ar-Rāhib. ${ }^{18}$ In the paragraph about the Byzantine emperor Anastasius (\$159), in the tabular chronological part of his History, Ibn ar-Rāhib remarks:

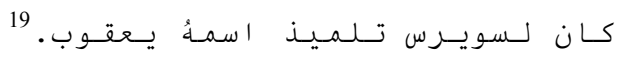

Severus had a disciple whose name was Jacob.

The historical works of Sa'îd ibn al-Bițrīq and Buțus ibn ar-Rāhib were employed by another Christian Arabic-speaking Egyptian author of the Coptic tradition Ğirğis al-Makīn ibn al- 'Amīd (12051273). ${ }^{20}$ In his account of the origins of the name "Jacobites," we do not only find a retelling of what had already been reported by earlier historians, but also a very peculiar theory concerning the origin of the name. Moreover, al-Makīn ibn al- 'Amīd unambiguously rejects the association of the term "Jacobites" with the name of Jacob Baradaeus, suggested by Sa 'ìd ibn al-Bitrīq! The first volume of al-Makin's world history, entitled by him The Blessed Compendium (al-Mağmū' al-mu$b \bar{a} r a k)$, still remains unpublished, so the relevant passages are quoted below from manuscripts containing the work (Paris BnF ar. $294^{21}$ and Vat. ar. 168 and $169^{22}$ ). Variant readings are given in the footnotes.

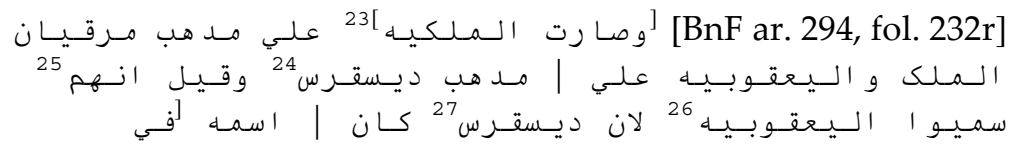

(18) A. SIDARUS, Ibn al-Rāhib, The Encyclopaedia of Islam, new edition, vol. XII: Supplement, Leiden, 2004, p. 396.

(19) L. CHeIKHO, Petrus Ibn Rahib. Chronicon orientale (CSCO; Scr. Ar., ser. 3, t. I), Beryti, Parisiis, 1903, p. 49 (text), p. 54 (Latin translation).

(20) G. GRAF, Geschichte der christlichen arabischen Literatur, Bd. 1-5 (ST, 133), Città del Vaticano, 1944-1953, Bd. 2, S. 348-351; H. Н. СЕлE3HEB, “«Коптский историк» - потомок выходца из Тикрита: Ал-Макйн ибн ал- 'Амйд и его «История» ["The Coptic Historian" - A descendant of an emigrant from Tikrit-al-Makīn ibn al- Amīd and his History]," Точкul Puncta, 1-2/10 (2011), c. 45-53.

(21) G. Troupeau, Catalogue des manuscrits arabes. Première partie: Manuscrits chrétiens, t. 1: ns 1-323, Paris, 1972, p. 261.

(22) A. MAI, Scriptorum veterum nova collectio e Vaticanis codicibus edita, t. IV: Codices Arabici, Romae, 1831, pp. 308-309.

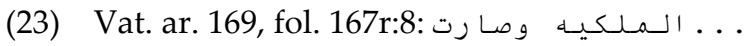

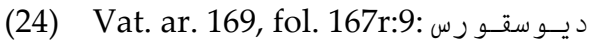

(25) Vat. ar. 168, fol. 187r:19: انـمـ

يعتـو بـيـه : Vat. ar. 168, fol. 187r:20, Vat. ar. 169, fol. 167r:9) 


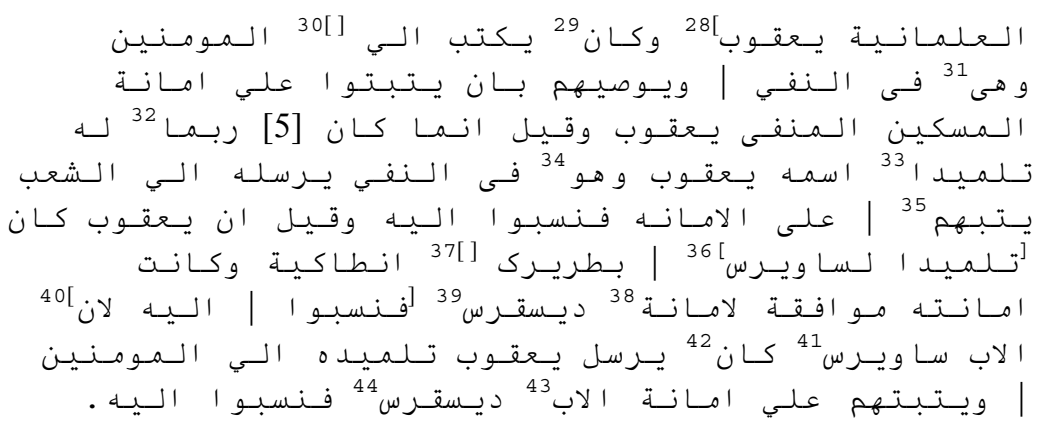

The Melkites followed the doctrine of the emperor Marcian, and the Jacobites - the doctrine of Dioscorus. It is said that they were called "Jacobites" because the lay name of Dioscorus was Jacob, and while in exile, he would write to the faithful and admonish them to hold firmly to the confession of the poor exile Jacob. And it is also said that perhaps he had a disciple named Jacob, and while in exile he would send him to the people to confirm them in the faith, and thus they were called so because of him. And it is also said that Jacob was a disciple of Severus, patriarch of Antioch, and his confession was in accordance with that of Severus, and thus they were called so because of him, since (father) Se-

(27) Vat. ar. 169, fol. 167r:10: ديـوسقـو رس

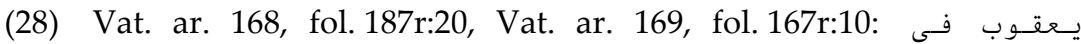

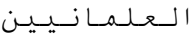

(29) Vat. ar. 168, fol. 187v:1, Vat. ar. 169, fol. 167r:11: فكـان

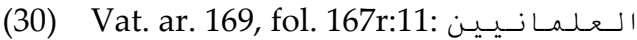

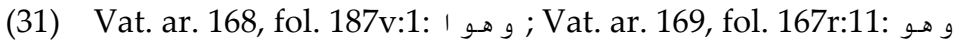

(32) Vat. ar. 168, fol. 187v:3, Vat. ar. 169, fol. 167r:12: abs.

(33) Vat. ar. 168, fol. 187v:3, Vat. ar. 169, fol. 167r:12:

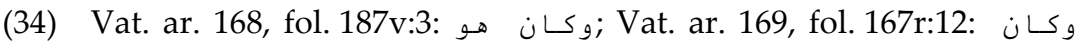
9

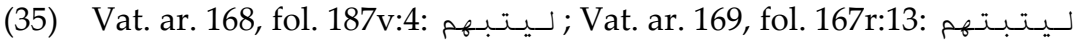

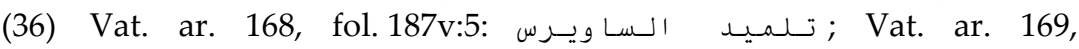
fol. 167r:14: تـلـميـد سـا و ريـوس

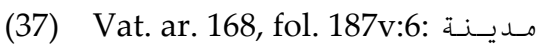

(38) Vat. ar. 168, fol. 187v:6: لامـــــ

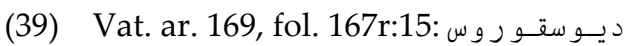

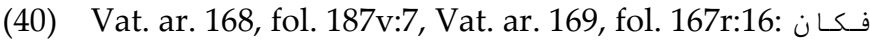

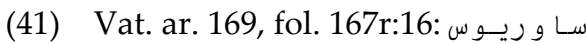

(42) Vat. ar. 168, fol. 187v:7, Vat. ar. 169, fol. 167r:16: abs.

(43) Vat. ar. 168, fol. 187v:8, Vat. ar. 169, fol. 167r:17: abs.

ديـوستـو روس : Vat. ar. 169, fol. 167r:17) 
verus would send Jacob, his disciple, to the faithful to confirm them in the faith of (father) Dioscorus, and thus they were called so because of him. ${ }^{45}$

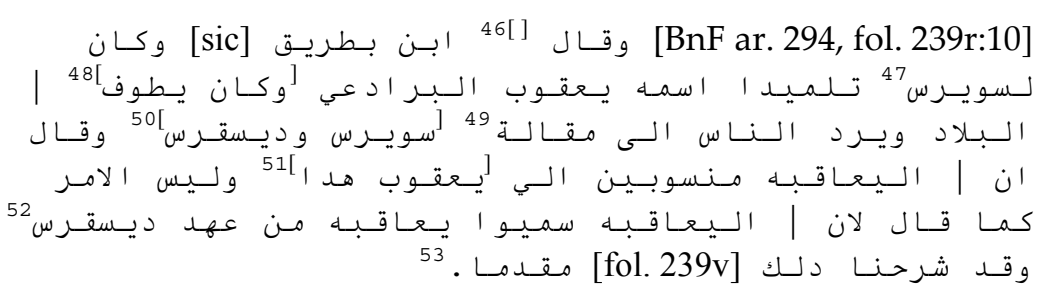

(Sa ${ }^{1} \overline{1}$ ) ibn [al-]Bițīq said: Severus had a disciple named Jacob Baradaeus (al-Barädi ' $\bar{\imath}$ - "Saddler"), and he would go about the country urging the people to return to the teaching of Severus and Dioscorus. He [i.e. Sa'îd ibn al-Bițrīq] said that Jacobites were called so because of this Jacob, but it is not as he said at all, because Jacobites had already been called Jacobites since the time of Dioscorus, as we explained earlier. ${ }^{54}$

Thus, we see that, according to the interpretation of al-Makin ibn al-'Amīd, Jacobites owe their name not to the architect of the antiChalcedonian hierarchy in Syria Jacob Baradaeus, but to the leader of the opposition to Chalcedon in Egypt the Pope of Alexandria Dioscorus (†454). Even when mentioning another version of the origin of the name "Jacobites," according to which Severus had a disciple named Jacob, al-Makin ibn al- 'Amīd took pains to emphasize that this Jacob was a propagator of the teachings of Dioscorus.

Later authors seem to have been slow to accept Ibn al- 'Amīd's interpretation, presented in the Blessed Compendium. In any event, such a famous Arabic-speaking Coptic author of the thirteenth-fourteenth

(45) al-Mağmū' al-mubārak. BnF ar. 294, fol. 232r; Vat. ar. 168, fol. 187r; Vat. ar. 169 , fol. 167r.

(46) Vat ar. 168, fol. 194r:12, Vat. ar. 169, fol. 171r:7: سعيــ

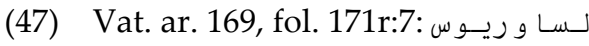

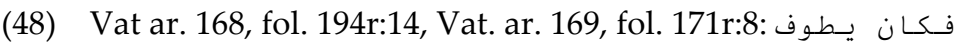

(49) Vat ar. 168, fol. 194r:14: مقـــا لـا

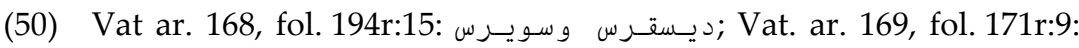
ديسوستـو روس و وسـا و ريـوس



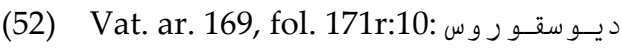

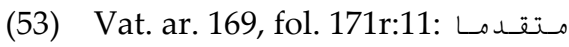

(54) al-Mă̆mū' al-mubārak. BnF ar. 294, fol. 239r; Vat. ar. 168, fol. 194r; Vat. ar. 169 , fol. 171 r. 
century as Abū-l-Barakāt ibn Kabar $(+1324)^{55}$ does not seem to have mentioned it at all. In his encyclopedic work Light [Dispelling] the Darkness and a Clear Explanation of the Liturgy (Miṣbạh az-zulma wa-īdāh al-hidma), he wrote:

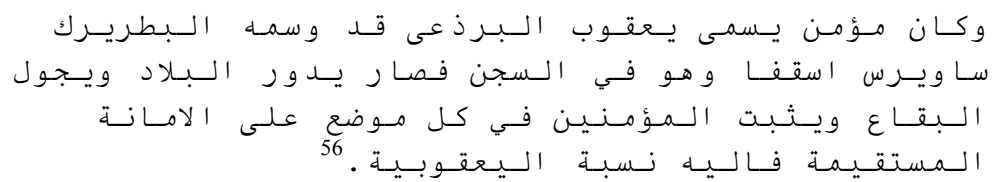

There was a faithful named Jacob Baradaeus (al-Barda $\underline{\imath}$ ) whom the patriarch Severus, being in exile, ordained a bishop. And he started going about the country and visiting places, confirming the faithful everywhere in the right faith. From him comes the name "Jacobites."

It is known that while composing his Light [Dispelling] the Dark$n e s s,{ }^{57}$ Ibn Kabar used the work of Sa 'îd ibn al-Bițīq, and his version of the origin of the name "Jacobites" seems to be nothing but a retelling of what he read there, with the only difference that the "discipleship" of Jacob was transformed into his episcopal ordination by Severus of Antioch. ${ }^{58}$ Neither does he invoke the association of the name "Jacobites" with Jacob of Sarug, even though we know that Ibn Kabar was familiar with the Summa of the Foundations of Religion by alMu'taman ibn al-'Assāl, where he could find this interpretation. ${ }^{59}$

At this point in our inquiry, we should turn to works of Muslim Egyptian authors to see how they interpret the origin of the term. Abū-l-'Abbās Aḥmad al-Qalqašandī (1355/6-1418), a clerk of the Mamlūk Sultans' dīwān, composed an encyclopedia of all knowledge that could be professionally useful to a high-ranking official, especially in the fields of documentation management and diplomacy. This

(55) E. Tisserant, L. Villecourt, G. Weit, "Recherches sur la personalité et la vie d'Abû'l-Barakât Ibn Kubr [sic]," Revue de l'Orient chrétien, 3 ${ }^{\text {ème }}$ série, 2/22:1 (1920-1921), pp. 373-394.

(56) L. Villecourt, E. Tisserant, G. Weit, Abû'l-Barakât [...] Ibn Kabar, Livre de la lampe des ténèbres et de l'exposition (lumineuse) du service (de l'Église) (PO, 20:4, No 99), Paris, 1928, repr. Turnhout, 1994, p. 733/[159].

(57) Livre de la lampe des ténèbres, p. 597/[23], p. 598/[24].

(58) Cf. a similar testimony in the Chronicle of Se'ert: A. SCHER, Histoire nestorienne (Chronique de Séert). Seconde partie (I) (PO, 7:2), Paris, 1909, repr. 1950, p. 141/[49].

(59) Livre de la lampe des ténèbres, pp. 597/[23], 599/[25]. 
14-volume work was entitled The Daybreak of the Weak-sighted [i.e. the recovery of their sight] on the Art of Composing [Official Documents] (Șubh al-a šā fì șinā at al-inša $\bar{a}$ ). ${ }^{60}$ Al-Qalqašandī collected information about various religious communities mainly with the purpose of using it in composing an efficient oath for those non-Muslims who would enter into interactions with the Muslim authorities. On Jacobites, he wrote, in particular, the following:

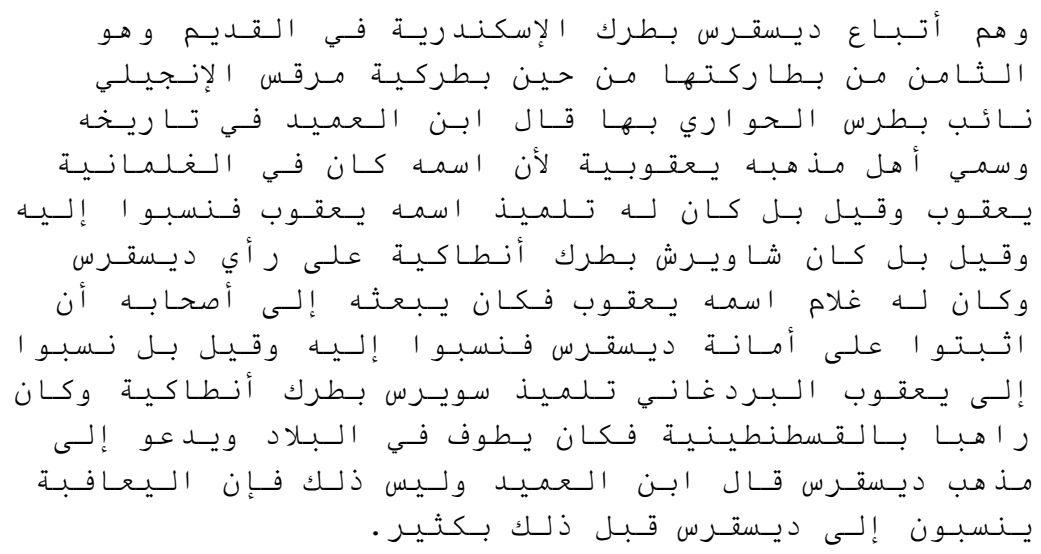

They are followers of Dioscorus who was patriarch of Alexandria in ancient times, being the eighth in the sequence of their patriarchs since the patriarchate of Mark the Evangelist, the successor to Peter the Apostle there. Ibn al- 'Amid in his History says that adherents of his doctrine were called "Jacobites" because his name in his youth (fi-l-gilmāniyya) was Jacob. But it is also said that he had a disciple named Jacob, and they were called so because of him. It is also said that Severus (Š̄̄wìruš), patriarch of Antioch who adhered to the opinion of Dioscorus, had a young servant named Jacob, and he would send him to his followers $<$ to instruct them $>$ to hold the faith of Dioscorus, and they were called so because of him. It is also said that they were called so after Jacob Baradaeus (al-Bardag் $\bar{a} n \bar{\imath})$, a disciple of Severus (Sāwìrus), patriarch of Antioch, who became a monk in Constantinople and then went about the country summoning [the people] to the doctrine of Di-

(60) Ab̄̄-l-'Abbās Aḥmad al-Qalqašandī, Șubh al-a šs̄ fi șinā'at al-inšă', 14 vols., al-Qāhirah, 1331-1338/1913-1919. 
oscorus. But Ibn al-'Amīd says: Nothing of the kind; Jacobites had been called so after Dioscorus long before <the time of Severus $>{ }^{.61}$

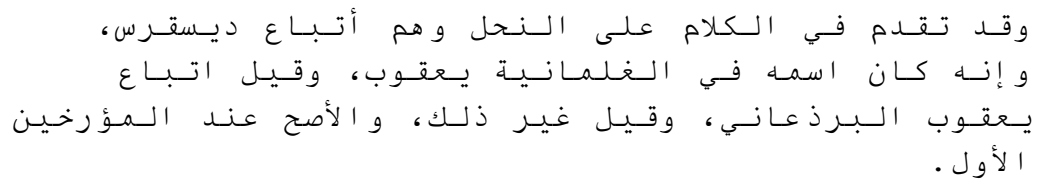

It has been said earlier in our section on the sects: They are the followers of Dioscorus, whose name in adolescence ( $f i-l$ gilmāniyya) was Jacob; other people say that they are the followers of Jacob Baradaeus (al-Bard $\left.\underline{d} a^{\prime} \bar{a} n \bar{\imath}\right)$; yet others provided a different explanation. However, the historians hold the view that the first $<$ explanation $>$ is the correct one. ${ }^{62}$

It is evident that al-Qalqašandi''s account is based on the Blessed Compendium of al-Makīn ibn al- 'Amīd. This is witnessed by the author's own indication as well as by the content of the text as a whole. It is noteworthy that al-Qalqašandi accepts the association of the name "Jacobites" with Dioscorus, called Jacob "in adolescence," as the "correct view," according to the historians. It should also be pointed out that there is a curious difference between the Blessed Compendium of al-Makīn ibn al- 'Amīd and in its retelling by al-Qalqašandī in how they designate the period when Dioscorus was called Jacob. According to the Blessed Compendium, "they were called 'Jacobites' because the name of Dioscorus as a layman was Jacob." "As a layman" reads as fi-l- 'almāniyya in BnF ar. 294, fol. 232r, i.e. "in worldliness" or "in/among the laity," if we read the word as an archaic plural form. In Vat. ar. 168, fol. $187 \mathrm{r}$ and Vat. ar. 169, fol. 167r, it reads fi-l'almāniyyīn, i.e. "in/among the laity." The reading "in adolescence" fi-l-gilmanniyya - probably originates from the fact that the word 'almāniyya, designating a characteristically Christian notion not typical of Muslim usage, was misunderstood either by al-Qalqašandī himself or by a copyist or editor of his work.

(61) Subh al-a '̌̌a fì șinā 'at al-inšs̄a', vol. 13, p. 278; al-Mağmū' al-mubārak, BnF ar. 294, fol. 239r; Vat. ar. 168, fol. 194r; Vat. ar. 169, fol. 171r. See the quotation above.

(62) Șubh al-a '̌̌a fì șinā'at al-inšà', vol. 11, p. 395; for an English translation of this passage see C. E. BOSWORTH, "Christian and Jewish Religious Dignitaries in Mamlûk Egypt and Syria: Qalqashandî's Information on Their Hierarchy, Titulature, and Appointment (II)," International Journal of Middle East Studies, 3:2 (1972), p. 204. 
Another Muslim Egyptian whose testimony concerning the origin of the name "Jacobites" is of interest to us is the famous Mamlūk historian and geographer Taqī ad-Dīn Aḥmad ibn 'Alī al-Maqrīzī (1364-1442). Eight chapters in the final part of his important work, The Book of Districts and Monuments in Egypt, in Cairo, and on the Nile, and the Reports Concerning Them (Kitāb al-Hitat wa-l-'ātār fì Mișr wa-lQāhira wa-n-Nīl wa-mā yata'allaqu bihā min al-'ahbārr) deal with the Copts. Being a great patriot of Egypt, al-Maqrīzī wrote a detailed description of the Coptic history and the church hierarchy - a very thorough account unmatched by any other medieval Muslim work. The name "Jacobites" and the various interpretations of its origin did not escape al-Maqrīzī's notice: ${ }^{63}$

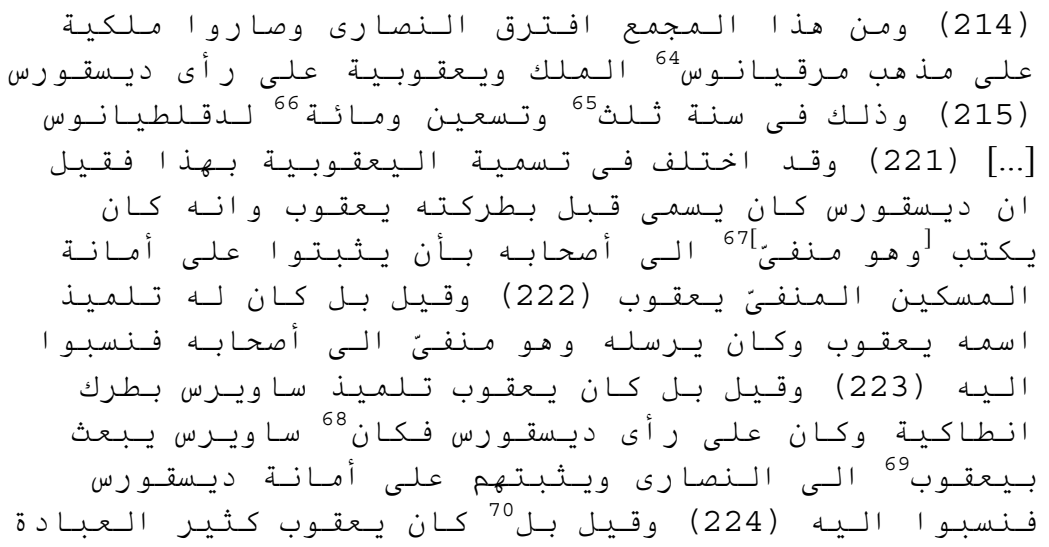

(63) Kitāb al-Hitat wa-l-'ātāēr fì Mișr wa-l-Qāhira wa-n-Nīl wa-mā yata allaqu bihā min al-'ahbār. [Editio princeps], Būlāq, 1270/1853, vol. 2, p. 489; H. J. Wetzer, Taki-eddini Makrizi, Historia Coptorum Christianorum in Aegypto Arabice, Solisbaci [Sulzbach], 1828, pp. 60, 62, 64 (text), pp. 61, 63, 65 (Latin translation); F. WÜsTENFELD, Macrizi's Geschichte der Copten, Göttingen, 1845, S. 16 (text), S. 40-41 (German translation). The quotation is taken from the editio princeps, and significant different readings in WETZER 1828 and WÜSTENFELD 1845 are provided in the footnotes. The numbering of the paragraphs is reproduced from WETZER 1828.

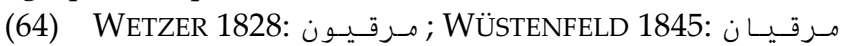

(65) WÜSTENFELD 1845: ثـــ

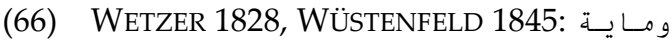

(67) WETZER 1828: ومـنفي

وكـان : We WeTZER 1828, WÜSTENFELD 1845

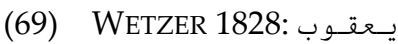

(70) WETZER 1828, WÜSTENFELD 1845: abs. 


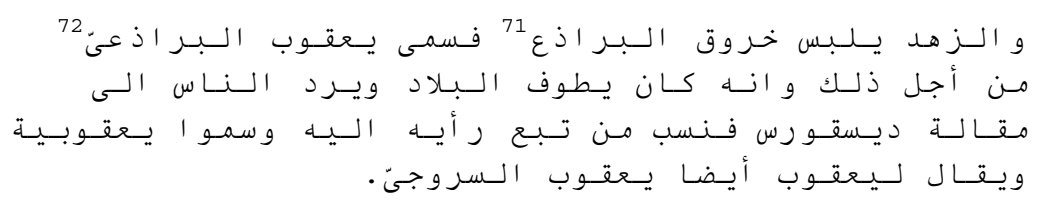

(214) After that council <i.e. the Council of Chalcedon> the Christians were divided. The Melkites followed the doctrine of the emperor Marcian, and the Jacobites, the opinion of Dioscorus. (215) This happened in the year 193 of [the era of] Diocletian. [...] (221) Yet as regards the name Jacobites, there is difference of opinion. Some say that Dioscorus, before he became patriarch, was called Jacob, and that he would write from his exile to his followers, that they should follow the faith of the poor exile Jacob. (222) Others say that he had a disciple named Jacob, and that during his exile he would send him to his followers, who took their name from him. (223) Others again say that Jacob was a disciple of Severus patriarch of Antioch, who was of Dioscorus' way of thinking, and that Severus would send this Jacob to the Christians, in order to confirm them in the faith of Dioscorus, and so they were called after him. (224) Others say that Jacob was a very pious and ascetic man who clothed himself in the shreds of saddle-cloths, which is why he was called Jacob Baradaeus (al-Barā $\underline{d} i i^{\prime} \bar{\imath}-$ "Saddler"), that he would go about the country, bringing people to the doctrine of Dioscorus, and that whoever adopted his views was called after him "Jacobite." And Jacob was also called Jacob of Sarug (asSarū $\bar{g} \bar{\imath}) .^{73}$

Obviously, al-Maqrīzī retold the information about Jacobites found in the Blessed Compendium of al-Makinn ibn al- 'Amīd (it is known that alMaqrīzì used the Blessed Compendium while composing his own work ${ }^{74}$ ) with the addition of a remark that identifies Jacob Baradaeus with Jacob of Sarug at the end of the passage. The "problematic" fi- $l$ 'almāniyya was skirted.



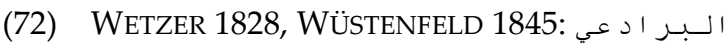

(73) I reproduce, with modifications, the English translation of S. C. MAlan (tr.), Ahmad ibn 'Alī al-Maqrīzì, A Short History of the Copts and of Their Church (Original documents of the Coptic Church, 3), London, 1873, pp. 58-59.

(74) И. Ю. КРАЧКОВСКИЙ, Избранные сочинения [Selected Works], т. 4, Москва, Ленинград, 1957; repr. as И. Ю. КРАчкОвСКИЙ, Арабская географическая литература [Arabic geographical Literature] (Классики отечественного востоковедения), Москва, 2004, с. 475. 
It should be noted that the idea that the name "Jacobites" comes from the lay name of the Pope of Alexandria Dioscorus, a hero of the Egyptian anti-Chalcedonians, was probably borrowed by al-Makin ibn al-'Amīd from unspecified Coptic texts, available to him. Later on, it spread widely and, it seems, became firmly rooted. There are later testimonies to its occurrence. Thus, for instance, Francesco Suriano (1450-1529), a Venetian Franciscan Friar, who traveled extensively in the Middle East, including Egypt, left us his travelogues which formed his Treatise on the Holy Land. ${ }^{75}$ While mentioning Jacobites, he states: "The Jacobites originate from the heretic Jacob, Patriarch of Alexandria in Egypt" ("Li Iacobiti sono derivati da Iacobo heretico Patriarcha de Alexandria de Hegypto"). ${ }^{76}$ Three centuries later, the English archeologist John Henry Middleton (1846-1896), in his article "The Copts of Egypt and Their Churches," published in the weekly The Academy, wrote the following: "The unorthodox party were called Jacobites, from Ya'gub (Jacob), the name of Dioscorus before he became Patriarch." 77

\section{CONCLUSION}

Based on the foregoing discussion, the following observations can be made.

1. The figure of Jacob Baradaeus has sometimes been overshadowed by that of Jacob of Sarug. This is witnessed, as shown above, by a seventh-century Greek text, by the Arabic Summa of a Coptic author, and by a comprehensive work, written by a medieval Muslim Egyptian historian. Strictly speaking, one cannot even be certain that for John of Damascus, "Jacob the Syrian" whom he mentions in his heresiographical treatise, meant Jacob Baradaeus. The poetic works of Jacob of Sarug gained popularity in all the traditions of Syriac Christianity,

(75) G. Golubovich, Il Trattato di Terra Santa e dell'Oriente di Frate Francesco Suriano, Missionario e Viaggiatore del Secolo XV (Siria, Palestina, Arabia, Egitto, Abissinia, ecc.), Milano, 1900; B. BAgAtTI, E. HoAdE (tr.) Francesco Suriano, Treatise on the Holy Land, Jerusalem, 1949.

(76) Il Trattato di Terra Santa e dell'Oriente, 78 (ch. 32); B. BAGATTI, E. HOADE 1949, p. 91.

(77) J. H. Middleton, "The Copts of Egypt and Their Churches," The Academy: A Weekly Review of Literature, Science, and Art, 22:543 (1882), p. 248, col. 2. 
and his fame can explain why it was sometimes his name that was associated with the adjective "Jacobite." Additionally, one could question the real significance of Jacob Baradaeus who is usually credited as a founder of the West-Syriac church tradition.

2. The formation and the development of the traditional Muslim heresiography contributed to the spread of the notion that Christians are divided into three principal denominations: the Nestorians, the Melkites, and the Jacobites. The idea that the three principal divisions embrace all the positions in Christian theology was likewise accepted among Eastern Christian thinkers. Thus, the linguistically, ethnically, and historically diverse communities of the opponents of Chalcedon were fused together in the single denomination of "Jacobites."78 Those of them who were in no way associated with the activity of Jacob Baradaeus - in particular, the anti-Chalcedonians of Egypt - were, therefore, motivated to find an alternative "explanation" for being identified as "Jacobites." This task became especially urgent following the process of arabization, which erased the most obvious cultural characteristics, differentiating them from their coreligionists of the SyroPalestinian region.

3. The theory concerning the origin of the name "Jacobites," presented by al-Makīn ibn al-'Amīd in his Blessed Compendium, conformed to the Coptic ideas about their place and role in the history of Eastern Christianity. In this Coptic version of the story, the Jacobites did not take their name from some poorly-dressed Syrian preacher, but from the brilliant Egyptian leader of the anti-Chalcedonian opposition: the Pope of Alexandria Dioscorus. This theory, obviously stem-

(78) An analogous question can certainly be posed concerning the designation "Melkites," in which both the Latin and the Byzantine church traditions were fused together, even though they became ecclesiastically separated later on. Subsequently, the name "Melkites" was appropriated by those of the Eastern Chalcedonians who entered the union with Rome. See Н.Н. СЕЛЕЗНЕВ, “«Мелькиты» в арабо-мусульманском традиционном религиоведении" [The "Melkites" in the Traditional Arab Muslim Religious Studies], Точки/Puncta, 3-4/10 (2011), c. 27-38. 
ming from the Coptic millieu, gained wide recognition, as witnessed by later Muslim and European sources.

\section{SUMMARY}

It is a conventional view that one of the most important denominations of Eastern Christianity - the Jacobites - owes its formation to the activity of the sixth-century Syrian bishop Jacob Baradaeus, and that it was called "Jacobite" after him. However, medieval sources show that the reality was more complex than that. Works by Egyptian Arabic authors, both Muslim and Christian, surveyed in this article, are of special interest because of a peculiar theory they advance: that the name "Jacobites" was derived from the lay name of Dioscorus, the Pope of Alexandria. The present study provides a comprehensive survey of the development of the different interpretations of the origins of the term. 